\title{
FATTY ACID, MINERAL AND PROXIMATE COMPOSITIONS OF VARIOUS GENOTYPES AND COMMERCIAL CULTIVARS OF SWEET ALMOND FROM THE SAME ECOLOGICAL CONDITIONS
}

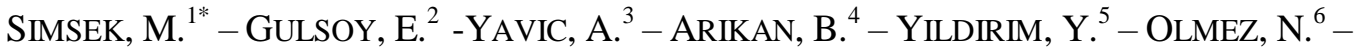 \\ ERDOGMUS, B. ${ }^{7}-$ BOGUC, $\mathrm{F}^{8}$ \\ ${ }^{I}$ Department of Horticulture, Faculty of Agriculture, Dicle University, Diyarbakir, Turkey \\ ${ }^{2}$ Department of Horticulture, Faculty of Agriculture, Igdir University, Igdir, Turkey \\ ${ }^{3}$ Department of Horticulture, Faculty of Agriculture, YYU University, Van, Turkey \\ ${ }^{4}$ Department of Horticulture, Institute of Sciences, Harran University, Sanliurfa, Turkey \\ ${ }^{5}$ Department of Horticulture, Institute of Sciences, YYU University, Van, Turkey \\ ${ }^{6}$ Ministry of Food, Agriculture and Livestock, Mardin Provincial Directorate, Mardin, Turkey \\ ${ }^{7}$ Ministry of Food, Agriculture and Livestock, Diyarbaktr Provincial Directorate, Diyarbakr, Turkey \\ ${ }^{8}$ Ministry of Food, Agriculture and Livestock, Şırnak Provincial Directorate, Şırnak, Turkey \\ *Corresponding author \\ e-mail: mikdat.simsek@dicle.edu.tr; phone: +90-412-241-1000,fax: +90-412-241-1048
}

(Received $17^{\text {th }}$ Feb 2018; accepted $9^{\text {th }}$ May 2018)

\begin{abstract}
This study was carried out on the fatty acid, mineral and proximate compositions of ten sweet almond genotypes and two commercial varieties named as Ferragnes and Ferraduel grown in the same ecological conditions known as the Firat riverside region during two consecutive years. In this context, the crude oil (Co), crude protein (Cp), total sugar (Ts), total ash (Ta) and moisture (Mo) contents from the almond genotypes and cultivars ranged from 48.69 to $55.8 \%, 20.41$ to $25.82 \%, 2.92$ to $5.27 \%, 3.29$ to $4.66 \%$ and 2.52 to $3.75 \%$, respectively. The genotypes and cultivars showed a varied mineral content as well. Potassium (K) was the main mineral in all genotypes and cultivars, ranging from 679.53 to 986.63 $\mathrm{mg} 100 \mathrm{~g}^{-1}$; phosphorus (P) was the second most abundant mineral, ranging from 584.57 to 697.31 $\mathrm{mg} 100 \mathrm{~g}^{-1}$; followed by magnesium (Mg) and calcium (Ca), ranging from 325.27 to $381.93 \mathrm{mg} 100 \mathrm{~g}^{-1}$, 250.15 to $332.19 \mathrm{mg} 100 \mathrm{~g} \mathrm{~g}^{-1}$, respectively. Of the identified fatty acids, oleic acid (Oa) (69.76-72.02\%) was the predominant fatty acid, followed by linoleic acid (La) (18.82-21.62\%), palmitic acid (Pa) $(5.62-$ $7.76 \%)$, and stearic acid (Sa) (1.20-1.69\%). Other fatty acids were present at trace amounts. The unsaturated (Ufa)/saturated fatty acid (Sfa) ratios ranged from 9.29 to 12.12. From the results of the present study, we can conclude that the kernels of almond genotypes and cultivars are being potential sources of valuable oil which might be used for edible and other industrial purposes.
\end{abstract}

Keywords: nut, ecology, chemical content, ANOVA, Turkey

\section{Introduction}

Sweet almond (Prunus amygdalus L.) is one of the important nut crops. It is cultivated and produced for multipurpose comparing to other commercial nuts in the world (Kester et al., 1991). Turkey is one of the significant countries in the world with respect to almond production. The total annual world almond production is about 3.214.303 tons. USA, Australia, Spain, Morocco, Iran and Syria produce 2.002.742, 
$72.709,202.339,112.681,147.863$ and 88.841 tons of almond annually, respectively. Turkey ranks seventh in the world, producing 85.000 tons of almond (FAO, 2016).

The fruits such as almond, walnut, pistachios and hazelnut, in which classification the almond seeds are generally included, are very requested products and their destinations are the direct consumption after toasting, the confectionery industry and the production of cakes, sweets, and almond candies (Piscopo et al., 2010; Simsek, 2016; Simsek et al., 2017). These fruits are typically high in fat but their fatty acid composition is advantageous in relation to risk of coronary heart disease (Lei et al., 2014). From the pre-agricultural era to the present day, almonds have been significant part of the human diet, providing micronutrients, macronutrients, and various bioactive constituents (Simsek, 2016). Kernels of almond genotypes and cultivars have been used to combat important diseases of the heart and autoimmune system, rheumatoid arthritis, and cancer in recent years (Jenkins et al., 2002).

The chemical composition of almond fruit is of great importance to establish its nutritive value and its quality for the recent concern of consumers over ensuring a healthy life style (Nanos et al., 2002; Simsek and Kizmaz, 2017). Fatty acid, mineral and proximate compositions of almond, pistachio, walnut, hazelnut and chestnut kernels are nutritionally very valuable (Bliss, 1999). These chemical contents can be influenced by ecological conditions, location and technical and cultural practices (Askin et al., 2007).

The proximate composition of ten sweet almond genotypes in Diyarbakir region ranged from 43.50 to $54.81 \%$ crude oil $(\mathrm{Co})$, from 21.18 to $32.90 \%$ crude protein $(\mathrm{Cp})$, from 3.08 to $4.43 \%$ moisture (Mo) and from 2.54 to $4.42 \%$ total ash (Ta) (Simsek and Demirkiran, 2010). The fatty acid compositions of almond genotypes ranged from 48.80 to $88.40 \%$ oleic acid (Oa), from 11.30 to $33.20 \%$ linoleic acid (La), from 4.60 to $9.50 \%$ palmitic acid ( $\mathrm{Pa}$ ) and from 1.00 to $3.40 \%$ stearic acid (Sa) (Kiani et al., 2015). In addition, the mineral contents of almond cultivars ranged from 525.46 to 793.86

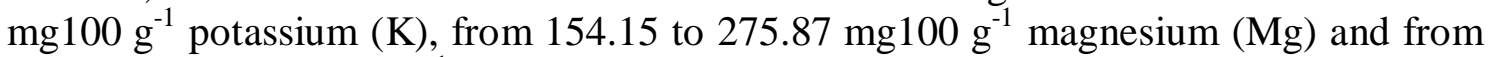

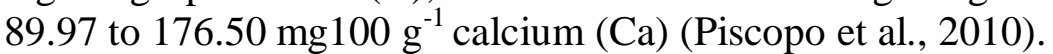

Many studies have been carried out especially dealing with the proximate, fatty acid and mineral compositions of almond genotypes grown in Turkey (Simsek and Demirkiran, 2010; Agar et al., 1998; Aslantas et al., 2001; Askin et al., 2007; Celik et al., 2010; Beyhan et al., 2011; Celik and Balta, 2011; Ozcan et al., 2011; Balta, 2013; Simsek and Kizmaz, 2017).

Hundreds of almond genotypes are grown in this location. They have grown heterozygously due to generative reproduction. So, the fruits that are handled may not be similar to each other as they can be. These genotypes have not been cultivated under regular care conditions. Ferragnes and Ferraduel almond varieties are also grown under good maintenance conditions. Because these varieties are vegetatively propagated, these have homozygote properties, the fruits obtained from these varieties are similar.

To our best of knowledge, no fatty acid, proximate and mineral composition studies on almond genotypes and cultivars have been reported in this area. Therefore, the present study is very significant. Therefore, the objectives of the present work were to determine the levels of significant fatty acid, mineral and proximate compositions in kernels of various genotypes and commercial cultivars of sweet almond. The study results are expected to contribute to breeding studies, commercial production, nutritional and technical applications, and healthy diets in future. 


\section{Materials and methods}

\section{Materials}

This study was carried out in the Firat riverside region of Hilvan district (Sanliurfa) of Southeast Turkey (FRH, 2018) in Figure 1. It has been stated that the soils in this region are sandy-loamy, calcified and / or humus and mostly rich in plant nutrients. In this area, a warm and temperate climate is prevalent. It receives more rainfall during winter time. Summers are generally hot and draught and as winters are temperate and wet and wet in Hilvan district with an altitude $591 \mathrm{~m}$ asl (CDO, 2018) and with an annual precipitation of $771.8 \mathrm{~mm}$ (Sanliurfa, 2018). In addition, temperature values of this region are given in Table 1 (CDO, 2018). Summers are arid and very hot, winters are rainy and partly temperate. The area of the province which is $55 \mathrm{~km}$ away from Sanliurfa is $1.278 \mathrm{~km}^{2}$ (IHI, 2018). In the Southeastern Anatolia Region, Şanliurfa province is surrounded by an illegal district of Hilvan, with Adiyaman and Siverek in the north, Siverek in the east, Central district in the south, Bozova in the south, and Adiyaman in the west. The district lands located in the northeastern part of Şanliurfa Plateau have a wavy land structure decreasing from the southeast to the southwest (IHI, 2018). The Firat riverside region of Hilvan district (Sanliurfa) of Southeast Turkey has a distinctive microclimatic environment derived from the Firat River. Ecological conditions around this river are similar mostly to those of Mediterranean region but are not similar to those of Sanliurfa province in the Southeast Anatolia region. In this ecology, there are also fruit trees such as almond, mulberry, pomegranate, figs, walnut, apricot, pistachio, cherry and forest trees such as pine, poplar and sycamore flourish (TSI, 2017). The fruits for determination of fatty acid, mineral and proximate compositions of ten genotypes and two commercial cultivars (Ferragnes and Ferraduel) of almond were harvested by hand during the years 2016-2017. After harvest, all samples of kernels were immediately dried and stored in their shells at room temperature until analysis.

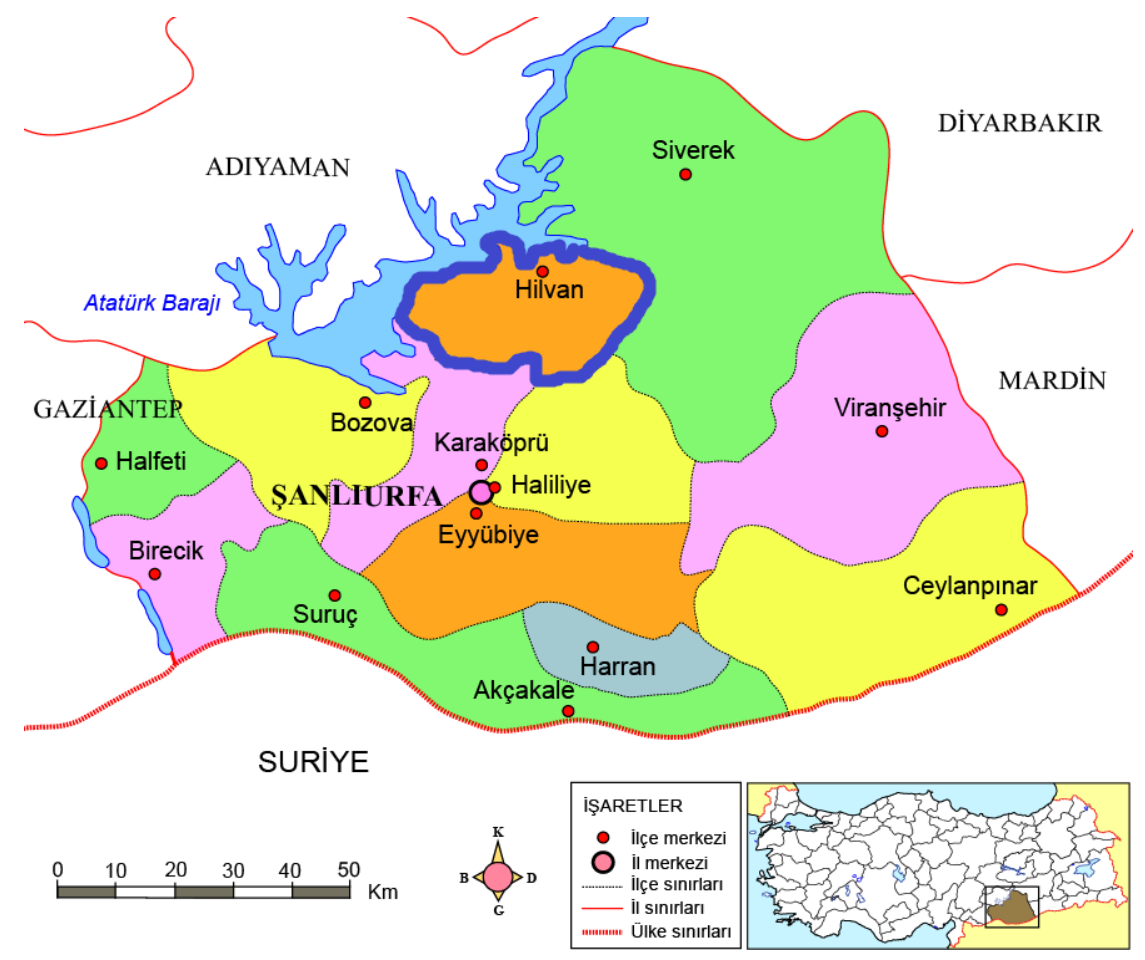

Figure 1. Map of districts in Sanliurfa province 
Table 1. Temperature parameters of Hilvan district of Sanliurfa province

\begin{tabular}{c|c|c|c|c|c|c|c|c|c|c|c|c}
\hline $\begin{array}{c}\text { Climatical } \\
\text { parameters }\end{array}$ & Jan & Feb & Mar & Apr & May & Jun & Jul & Aug & Sep & Oct & Nov & Dec \\
\hline $\begin{array}{c}\text { Avg. temp. } \\
\left({ }^{\circ} \mathrm{C}\right)\end{array}$ & 4.60 & 6.10 & 10.10 & 15.10 & 20.60 & 26.40 & 30.60 & 30.2 & 26.20 & 19.40 & 12.40 & 7.00 \\
$\begin{array}{c}\text { Min. temp. } \\
\left({ }^{\circ} \mathrm{C}\right)\end{array}$ & 1.00 & 2.20 & 5.30 & 9.50 & 14.10 & 19.50 & 23.50 & 23.10 & 19.10 & 13.30 & 7.30 & 3.10 \\
$\begin{array}{c}\text { Max. temp. } \\
\left({ }^{\circ} \mathrm{C}\right)\end{array}$ & 8.30 & 10.10 & 15.00 & 20.80 & 27.10 & 33.30 & 37.80 & 37.40 & 33.30 & 25.60 & 17.50 & 10.90 \\
\hline
\end{tabular}

Since the characteristics of local almond genotypes and varieties were not affected by any year, the average values of 2 years were evaluated as a whole. Furthermore, chemical analysis for fatty acids, proximate acids and minerals is very expensive. Therefore, in a number of previous studies averages of a maximum of 2 years are evaluated on their contents. Therefore, samples of $30 \mathrm{~g}$ (10 g kernel x three replications) for every genotype or cultivar were taken from ten sweet almond genotypes and from two commercial varieties in each year.

\section{Proximate composition of sweet almond genotypes and cultivars}

The almonds were dried and stored in their shells at room temperature prior to analysis. The samples were finely grinded and their moisture (Mo) content was determined before the proximate analysis. Moisture (Mo) content was analyzed and calculated according to the methods given by the Turkish Standard Institute (AOAC, 1990). For crude oil (Co) analyses, the samples were homogenized and subjected to extraction for $6 \mathrm{~h}$ with petroleum ether (boiling range 30-60 ${ }^{\circ} \mathrm{C}$ ) in a Soxhlet apparatus. The extracted total crude oil was dried over anhydrous sodium sulphate and the solvent was removed under reduced pressure in a rotary film evaporator. Crude oil (Co) percentages of the genotypes and cultivars were determined by weight difference (AOAC, 1990). Total ash (Ta) content was determined in crucible to a muffle furnace at $900{ }^{\circ} \mathrm{C}$ for $8 \mathrm{~h}$ (AOAC, 1990). Total sugar (Ts) content was determined by the Anthrone method (Kaplankiran, 1984). The nitrogen content was estimated by the Kjeldahl method and was converted to crude protein $(\mathrm{Cp})$ content by using the conversion factor 6.25 (AOAC, 1990).

\section{Mineral composition of sweet almond genotypes and cultivars}

The magnesium $(\mathrm{Mg})$, calcium $(\mathrm{Ca})$, iron $(\mathrm{Fe})$, copper $(\mathrm{Cu})$, zinc $(\mathrm{Zn})$ and manganese $(\mathrm{Mn})$ contents were determined via Perkin Elmer 703 atomic absorption spectrophotometry, and the sodium and potassium $(\mathrm{K})$ contents were measured via flame emission spectrometry. Phosphorus (P) was measured by colorimetric method (Saura Calixto and Canellās, 1982; Simsek and Kizmaz, 2017).

\section{Fatty acid composition of sweet almond genotypes and cultivars}

The crude oil (Co) contents were determined according to standard procedure (AOAC, 1990). For the preparation of fatty acid methyl esters (FAMEs) $0.4 \mathrm{~g}$ crude oil (Co) of the kernel samples were dissolved in $4 \mathrm{~mL}$ of isooctane and methylated in $0.2 \mathrm{~mL} 2 \mathrm{M}$ methanolic $\mathrm{KOH}$. Analysis of FAMEs was performed on an Agilent 6890 
series Gas Chromatography equipped with flame-ionization detector and a $60 \mathrm{~m}$ capillary column (internal diameter $=0.25 \mathrm{~mm}$ ) coated with $0.25 \mu \mathrm{m}$ of $50 \%$ cyanopropyl-methylpolysiloxane (J\&W Scientific, Folsom, CA, USA). Helium was used as a carrier gas at a flow rate of $1.5 \mathrm{~mL} \mathrm{~min}^{-1}$ and a split ratio of 1:10. The temperatures of the injector and detector were $250{ }^{\circ} \mathrm{C}$ and $260{ }^{\circ} \mathrm{C}$, respectively. The oven was programmed to hold at $120{ }^{\circ} \mathrm{C}$ for a $5 \mathrm{~min}$, and then to increase the temperature to $240{ }^{\circ} \mathrm{C}$ at a rate of $15^{\circ} \mathrm{C} \mathrm{min}-1$ and to hold that temperature for $20 \mathrm{~min}$ (Basturk et al., 2007). FAMEs were identified by comparison of their retention times and equivalent chain lengths in terms of standard FAMEs (Supelco. 47885-U). FAMEs of samples were quantified according to their percentage areas (AOAC, 1990).

\section{Statistical analysis of sweet almond genotypes and cultivars}

Statistical analyses of proximate, fatty acid and mineral compositions of sweet almond genotypes and cultivars were performed in triplicate. All data were subjected to analysis of variance using JMP 5.0.1 (one-way ANOVA).

\section{Results}

Proximate composition of sweet almond genotypes and cultivars are shown in Table 2. According to this table, crude oil (Co), crude protein $(\mathrm{Cp})$, total ash (Ta), moisture (Mo) and total sugar (Ts) contents of 10 almond genotypes and two commercial almond cultivars ranged from 48.69 (SAHI301) to $55.81 \%$ (FERRAGNES), from 20.41 (FERRAGNES) to $25.82 \%$ (SAHI301), from 3.29 (SAHI278) to 4.66\% (SAHI6), from 2.52 (SAHI6) to 3.96\% (SAHI324) and from 2.97 (FERRADUEL) to $5.27 \%$ (SAHI72), respectively.

Table 2. Proximate composition of sweet almond genotypes and cultivars (\%) (average 2016-2017)

\begin{tabular}{c|c|c|c|c|c}
\hline G \& C & Mo $(\%)$ & Co $(\%)$ & Cp $(\%)$ & Ta $(\%)$ & Ts $(\%)$ \\
\hline SAHI6 & $2.52 \mathrm{f}$ & $51.13 \mathrm{~d}$ & $25.67 \mathrm{a}$ & $4.66 \mathrm{a}$ & $3.31 \mathrm{gh}$ \\
SAHI36 & $2.79 \mathrm{ef}$ & $51.72 \mathrm{~cd}$ & $24.37 \mathrm{~b}$ & $3.47 \mathrm{ef}$ & $3.57 \mathrm{fg}$ \\
SAHI72 & $3.39 \mathrm{bc}$ & $52.10 \mathrm{c}$ & $21.99 \mathrm{e}$ & $3.30 \mathrm{f}$ & $5.27 \mathrm{a}$ \\
SAHI132 & $3.21 \mathrm{c}$ & $55.69 \mathrm{a}$ & $20.54 \mathrm{f}$ & $3.48 \mathrm{ef}$ & $3.73 \mathrm{efg}$ \\
SAHI198 & $3.70 \mathrm{ab}$ & $52.10 \mathrm{c}$ & $22.94 \mathrm{~d}$ & $3.81 \mathrm{de}$ & $3.89 \mathrm{ef}$ \\
SAHI232 & $2.87 \mathrm{de}$ & $51.53 \mathrm{~cd}$ & $24.69 \mathrm{~b}$ & $3.63 \mathrm{def}$ & $4.54 \mathrm{~cd}$ \\
SAHI250 & $3.23 \mathrm{c}$ & $48.93 \mathrm{e}$ & $23.55 \mathrm{c}$ & $4.52 \mathrm{ab}$ & $5.07 \mathrm{abc}$ \\
SAHI278 & $3.41 \mathrm{bc}$ & $52.10 \mathrm{c}$ & $21.89 \mathrm{e}$ & $3.29 \mathrm{f}$ & $5.17 \mathrm{ab}$ \\
SAHI301 & $3.58 \mathrm{~b}$ & $48.69 \mathrm{e}$ & $25.82 \mathrm{a}$ & $4.21 \mathrm{bc}$ & $4.13 \mathrm{de}$ \\
SAHI324 & $3.96 \mathrm{a}$ & $51.80 \mathrm{~cd}$ & $23.40 \mathrm{~cd}$ & $3.92 \mathrm{~cd}$ & $4.63 \mathrm{bcd}$ \\
FERRADUEL & $3.15 \mathrm{~cd}$ & $54.71 \mathrm{~b}$ & $21.74 \mathrm{e}$ & $4.64 \mathrm{a}$ & $2.97 \mathrm{~h}$ \\
FERRAGNES & $3.13 \mathrm{~cd}$ & $55.81 \mathrm{a}$ & $20.41 \mathrm{f}$ & $3.35 \mathrm{f}$ & $5.08 \mathrm{abc}$ \\
LSD & 0.40 & 0.77 & 0.60 & 0.37 & 0.56 \\
\hline
\end{tabular}

*Statistically significant (at 0.05 level). Moisture: Mo, Crude Oil: Co, Crude Protein: Cp, Total Ash: Ta, Total Sugar: Ts, Genotypes \& Cultivars: G \& C 
The amount of the minerals studied in the sweet almond genotypes and cultivars are shown in Table 3, referred to non-dried matter. According to this table, among the genotypes and cultivars studied, SAHI36 genotype contained the highest potassium (K) (986.63 mg100 g $\mathrm{g}^{-1}$ ). The phosphorus (P), magnesium (Mg), and calcium (Ca) contents

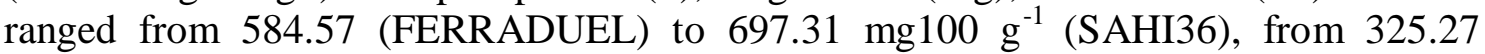
(SAHI132) to $381.93 \mathrm{mg} 100 \mathrm{~g}^{-1}$ (SAHI324) and from 250.15 (SAHI250) to $332.19 \mathrm{mg} 100 \mathrm{~g}^{-1}$ (SAHI198), respectively. Sodium (Na), iron (Fe), zinc ( $\mathrm{Zn}$ ), manganese $(\mathrm{Mn})$ and copper $(\mathrm{Cu})$ amounts ranged from 9.20 (SAHI301) to $16.06 \mathrm{mg} 100 \mathrm{~g}^{-1}$ (SAHI72), from 6.08 (FERRAGNES) to $10.62 \mathrm{mg}^{100 \mathrm{~g}^{-1}}$ (SAHI6),

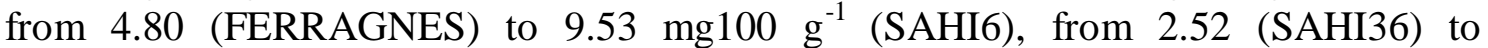
$4.76 \mathrm{mg} 100 \mathrm{~g}^{-1}$ (SAHI72) and from $2.02 \mathrm{mg} 100 \mathrm{~g}^{-1}$ (SAHI250) to 3.97 (SAHI232), respectively.

Table 3. Mineral compositions of sweet almond genotypes and cultivars ( $m g 100 \mathrm{~g}^{-1}$ ) (average 2016-2017)

\begin{tabular}{|c|c|c|c|c|c|}
\hline $\mathbf{G} \& \mathbf{C}$ & K & \multicolumn{2}{|c|}{$\mathbf{P}$} & Mg & Ca \\
\hline SAHI6 & $783.37 \mathrm{e}$ & \multicolumn{2}{|c|}{$590.12 \mathrm{e}$} & $366.30 \mathrm{ab}$ & $284.93 b c$ \\
\hline SAHI36 & $986.63 \mathrm{a}$ & \multicolumn{2}{|c|}{$697.31 \mathrm{a}$} & $342.06 \mathrm{ab}$ & $275.37 \mathrm{~cd}$ \\
\hline SAHI72 & $783.3 \mathrm{e}$ & \multicolumn{2}{|c|}{ 591.16de } & $361.57 \mathrm{ab}$ & $285.47 b c$ \\
\hline SAHI132 & $875.83 \mathrm{bcd}$ & \multicolumn{2}{|c|}{ 594.31de } & $225.27 \mathrm{c}$ & $189.63 \mathrm{e}$ \\
\hline SAHI198 & $859.03 \mathrm{~cd}$ & \multicolumn{2}{|c|}{ 637.79abc } & $363.67 \mathrm{ab}$ & $332.19 \mathrm{a}$ \\
\hline SAHI232 & $947.76 \mathrm{a}$ & \multicolumn{2}{|c|}{$612.21 \mathrm{cde}$} & $332.32 \mathrm{a}$ & $285.87 b c$ \\
\hline SAHI250 & $842.25 d$ & \multicolumn{2}{|c|}{$648.60 \mathrm{bc}$} & $332.10 b$ & $250.15 d$ \\
\hline SAHI278 & $679.53 \mathrm{f}$ & \multicolumn{2}{|c|}{$616.04 \mathrm{cde}$} & $353.21 \mathrm{ab}$ & $312.25 \mathrm{ab}$ \\
\hline SAHI301 & $900.57 b c$ & \multicolumn{2}{|c|}{$671.14 \mathrm{ab}$} & $342.04 \mathrm{ab}$ & $281.78 \mathrm{c}$ \\
\hline SAHI324 & $845.60 \mathrm{~d}$ & \multicolumn{2}{|c|}{$668.43 \mathrm{ab}$} & $381.93 \mathrm{a}$ & $324.54 \mathrm{a}$ \\
\hline FERRADUEL & $903.30 \mathrm{~b}$ & \multicolumn{2}{|c|}{$584.37 \mathrm{e}$} & $375.10 \mathrm{a}$ & $321.78 \mathrm{a}$ \\
\hline FERRAGNES & $879.43 \mathrm{bcd}$ & \multicolumn{2}{|c|}{$621.55 \mathrm{cde}$} & $366.07 \mathrm{ab}$ & $276.98 \mathrm{~cd}$ \\
\hline LSD & 77.55 & \multicolumn{2}{|c|}{46.86} & 40.22 & 27.54 \\
\hline \multicolumn{6}{|c|}{ Continued... } \\
\hline $\mathbf{G} \& \mathbf{C}$ & $\mathrm{Na}$ & Fe & $\mathbf{Z n}$ & Mn & $\mathrm{Cu}$ \\
\hline SAHI6 & $15.37 \mathrm{ab}$ & $10.62 \mathrm{a}$ & $9.53 \mathrm{a}$ & $4.44 \mathrm{ab}$ & $3.45 \mathrm{ab}$ \\
\hline SAHI36 & $11.70 f$ & $8.49 \mathrm{~cd}$ & $7.59 \mathrm{de}$ & $2.52 \mathrm{e}$ & $3.59 \mathrm{a}$ \\
\hline SAHI72 & $16.06 \mathrm{a}$ & $9.57 \mathrm{~b}$ & $8.70 b c$ & $4.76 \mathrm{a}$ & $3.57 \mathrm{a}$ \\
\hline SAHI132 & $9.58 \mathrm{~g}$ & $7.26 \mathrm{ef}$ & $5.64 \mathrm{~g}$ & $4.00 \mathrm{bc}$ & $2.70 \mathrm{~cd}$ \\
\hline SAHI198 & $13.50 \mathrm{~cd}$ & $6.14 \mathrm{~g}$ & $5.71 \mathrm{~g}$ & $4.07 \mathrm{~b}$ & $3.44 \mathrm{ab}$ \\
\hline SAHI232 & $11.47 f$ & $8.58 \mathrm{c}$ & $7.99 \mathrm{~d}$ & $2.87 \mathrm{de}$ & $3.97 \mathrm{a}$ \\
\hline SAHI250 & $13.01 \mathrm{de}$ & $9.14 b c$ & $8.03 \mathrm{~cd}$ & $3.93 b c$ & $2.02 \mathrm{e}$ \\
\hline SAHI278 & $10.96 f$ & $7.83 \mathrm{de}$ & $6.92 \mathrm{ef}$ & $2.54 \mathrm{e}$ & $3.40 \mathrm{ab}$ \\
\hline SAHI301 & $9.20 \mathrm{~g}$ & $9.56 b$ & $8.92 \mathrm{ab}$ & $4.59 \mathrm{ab}$ & $2.17 \mathrm{de}$ \\
\hline SAHI324 & $11.96 \mathrm{ef}$ & 7.18ef & $6.79 f$ & $4.06 \mathrm{bc}$ & $3.49 \mathrm{ab}$ \\
\hline FERRADUEL & $14.50 \mathrm{bc}$ & $6.68 \mathrm{fg}$ & $5.53 \mathrm{~g}$ & $3.40 \mathrm{~cd}$ & $2.93 \mathrm{bc}$ \\
\hline FERRAGNES & $10.92 f$ & $6.08 \mathrm{~g}$ & $4.80 \mathrm{~h}$ & $2.82 \mathrm{de}$ & $2.89 b c$ \\
\hline LSD & 1.06 & 0.71 & 0.69 & 0.68 & 0.6 \\
\hline
\end{tabular}

*Statistically significant (at 0.05 level). Potassium: K, Phosphor: P, Magnesium: Mg, Calcium: Ca, Sodium: Na, Iron: Fe, Zinc: Zn, Manganese: Mn, Copper: Cu, Genotypes \& Cultivars: G\&C 
Fatty acid composition of promising almond genotypes and cultivars are shown in Table 4. According to this table, while oleic acid (Oa) content ranged from 69.76 (SAHI232) and 72.02\% (SAHI250), linoleic acid (La) content changed from 18.82 (SAHI72) to $21.62 \%$ (SAHI232) in the samples. Palmitic acid (Pa) contents were found from 5.62 (SAHI132) and 7.76\% (SAHI301) in the samples (Table 3). The stearic (Sa), myristic (Ma), palmitoleic (Paa) and linolenic acid (Lia) contents ranged from 1.20 (SAHI198) to $1.69 \%$ (SAHI72), from 0.27 (SAHI250) to 0.55\% (FERRADUEL), from 0.19 (SAHI301) to $0.54 \%$ (SAHI72), and from 0.07 to $0.09 \%$, respectively.

Table 4. Fatty acid composition of promising almond genotypes and cultivars (\%) (average 2016-2017)

\begin{tabular}{c|c|c|c|c|c|c|c}
\hline G \& C & Pa & Sa & Ma & Paa & Oa & La & Lia \\
\hline SAHI6 & $6.35 \mathrm{~cd}$ & $1.46 \mathrm{abc}$ & $0.47 \mathrm{ab}$ & $0.40 \mathrm{abc}$ & $8.68 \mathrm{~b}$ & $19.91 \mathrm{~b}-\mathrm{e}$ & $19.91 \mathrm{~b}-\mathrm{e}$ \\
SAHI36 & $6.26 \mathrm{~cd}$ & $1.57 \mathrm{ab}$ & $0.47 \mathrm{ab}$ & $0.21 \mathrm{~cd}$ & $8.52 \mathrm{bc}$ & $19.89 \mathrm{be}$ & $19.89 \mathrm{~b}-\mathrm{e}$ \\
SAHI72 & $6.94 \mathrm{~b}$ & $1.69 \mathrm{a}$ & $0.40 \mathrm{bc}$ & $0.54 \mathrm{a}$ & $9.57 \mathrm{a}$ & $18.82 \mathrm{e}$ & $18.82 \mathrm{e}$ \\
SAHI132 & $5.62 \mathrm{e}$ & $1.39 \mathrm{abc}$ & $0.34 \mathrm{bc}$ & $0.20 \mathrm{~cd}$ & $7.62 \mathrm{f}$ & $20.46 \mathrm{~b}$ & $20.46 \mathrm{~b}$ \\
SAHI198 & $6.20 \mathrm{~d}$ & $1.20 \mathrm{c}$ & $0.37 \mathrm{bc}$ & $0.31 \mathrm{bcd}$ & $8.09 \mathrm{de}$ & $20.11 \mathrm{bc}$ & $20.11 \mathrm{bc}$ \\
SAHI232 & $6.44 \mathrm{~cd}$ & $1.35 \mathrm{bc}$ & $0.46 \mathrm{ab}$ & $0.28 \mathrm{~cd}$ & $8.53 \mathrm{bc}$ & $21.62 \mathrm{a}$ & $21.62 \mathrm{a}$ \\
SAHI250 & $6.10 \mathrm{~d}$ & $1.23 \mathrm{c}$ & $0.27 \mathrm{c}$ & $0.31 \mathrm{~cd}$ & $7.91 \mathrm{ef}$ & $20.00 \mathrm{bcd}$ & $20.00 \mathrm{bcd}$ \\
SAHI278 & $6.18 \mathrm{~d}$ & $1.35 \mathrm{bc}$ & $0.43 \mathrm{ab}$ & $0.33 \mathrm{bcd}$ & $8.29 \mathrm{~cd}$ & $19.68 \mathrm{be}$ & $19.68 \mathrm{~b}-\mathrm{e}$ \\
SAHI301 & $7.76 \mathrm{a}$ & $1.40 \mathrm{abc}$ & $0.38 \mathrm{bc}$ & $0.19 \mathrm{~d}$ & $9.73 \mathrm{a}$ & $19.00 \mathrm{de}$ & $19.00 \mathrm{de}$ \\
SAHI324 & $6.68 \mathrm{bc}$ & $1.34 \mathrm{bc}$ & $0.34 \mathrm{bc}$ & $0.50 \mathrm{ab}$ & $8.86 \mathrm{~b}$ & $20.04 \mathrm{bcd}$ & $20.04 \mathrm{bcd}$ \\
FERRADUEL & $6.99 \mathrm{~b}$ & $1.67 \mathrm{a}$ & $0.55 \mathrm{a}$ & $0.34 \mathrm{bcd}$ & $9.55 \mathrm{a}$ & $20.47 \mathrm{~b}$ & $20.47 \mathrm{~b}$ \\
FERRAGNES & $6.72 \mathrm{bc}$ & $1.51 \mathrm{abc}$ & $0.41 \mathrm{abc}$ & $0.21 \mathrm{~cd}$ & $8.85 \mathrm{~b}$ & $19.06 \mathrm{cde}$ & $19.06 \mathrm{cde}$ \\
LSD & 0.46 & 0.31 & 0.15 & 0.19 & 1.13 & 1.11 & 0.01 \\
\hline
\end{tabular}

*Statistically significant (at 0.05 level). Palmitic acid: Pa, Stearic acid: Sa, Myristic acid: Ma, Palmitoleic acid: Paa, Oleic acid: Oa, Linoleic acid: La, Linolenic acid: Lia, UFA: Unsaturated fatty acids, SFA: Saturated fatty acids, Genotypes \& Cultivars: G\&C

SFA, UFA and UFA/SFA ratios of sweet almond genotypes and cultivars are shown in Figures 2, 3 and 4, respectively. In this context, SFA, UFA and UFA/SFA ratios of samples ranged from 7.62 (SAHI198) to 9.73\% (FERRADUEL), from 90.27 (SAHI301) to $92.09 \%$ (SAHI250) and from 9.29 (SAHI301) to $12.12 \%$ (SAHI132), respectively.

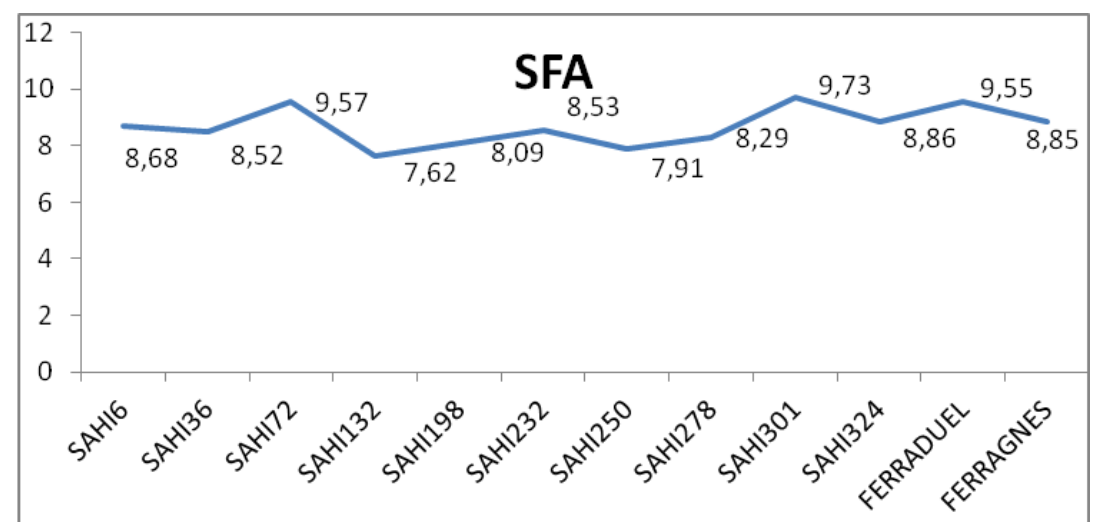

Figure 2. The SFA ratios of sweet almond genotypes and cultivars (average 2016-2017) 


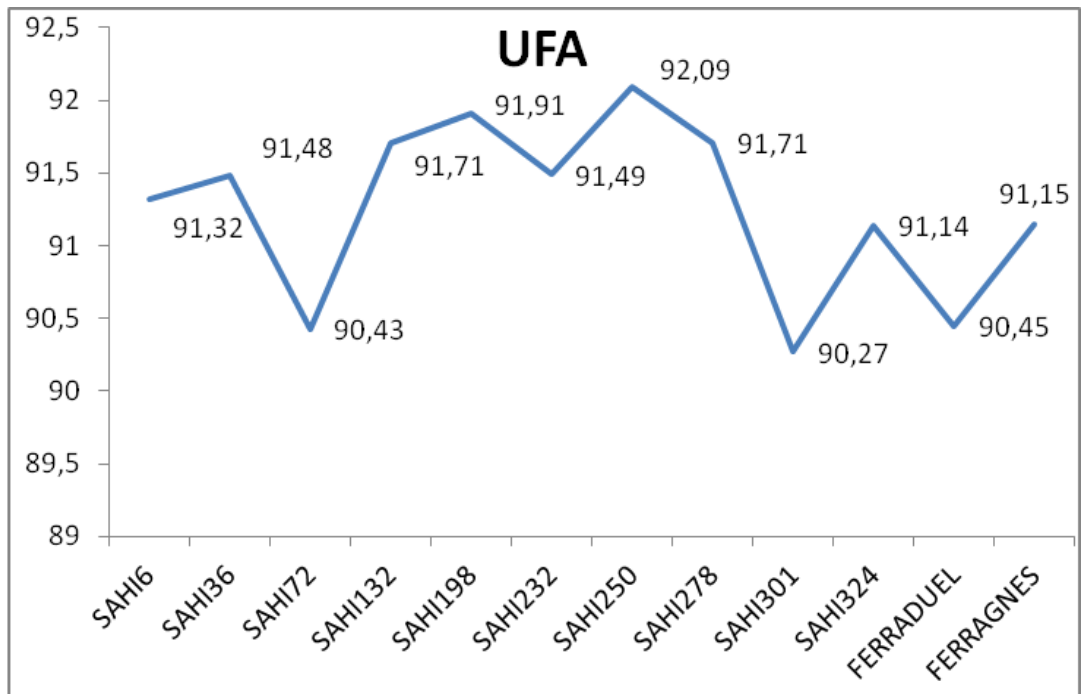

Figure 3. The UFA ratios of sweet almond genotypes and cultivars (average 2016-2017)

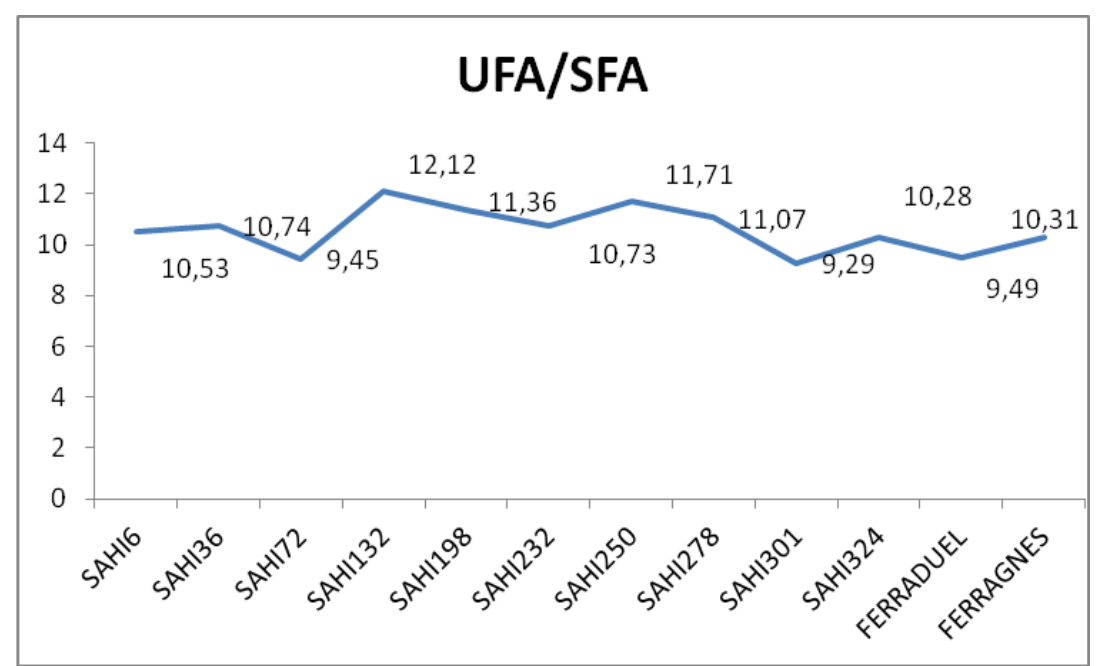

Figure 4. The UFA/SFA ratio of sweet almond genotypes and cultivars (average 2016-2017)

\section{Discussion}

\section{Proximate composition of sweet almond genotypes and cultivars}

This study was carried out on the almond genotypes and commercial varieties named as Ferragnes and Ferraduel grown in the same location known as the Firat riverside region during two consecutive years. In this study, proximate contents of the genotypes and varieties were compared at the same location. According to the results from the one-way ANOVA analysis, the differences between the proximate composition of the genotypes and/or the varieties were shown in different letters statistically and were presented in Table 2. In this context in this study, the samples of sweet almond genotypes and cultivars showed only a relatively small variation. Crude oil (Co) content is a relatively stable feature independent on the different almond genotypes and cultivars. All genotypes and varieties except for SAHI250 and SAHI301 genotypes are rich in crude oil because their crude oil content is greater than $50 \%$. In various almond 
varieties that differed in genotypes, the oil (Co) contents were previously reported to range from 43.50 to $54.81 \%$ (Simsek and Demirkiran, 2010), from 52.08 to $57.49 \%$ (Agar et al., 1998), from $48.80 \%$ to $55.70 \%$ (Ozcan et al., 2011), from 52.00 to $56.00 \%$ (Barbera et al., 1984), from 53.00 to $62.00 \%$ (García-López et al., 1996), from 30.0 to $51.00 \%$ (Martins et al., 2000) and from 48.93 to 55.96\% (Simsek and Kizmaz, 2017). In the present study, the oil (Co) contents were partly similar to those previously recorded. The almond kernel has high crude oil (Co) content, and the kernels do not constitute a bulky diet. Since all genotypes and varieties have crude protein values greater than $20 \%$, they are protein rich. In various works, the crude protein $(\mathrm{Cp})$ content varied from 22.50 to $25.80 \%$ (Barbera et al., 1984), from 18.00 to $25.00 \%$ (Soler et al., 1989), from 14.50 to $24.00 \%$ (Mbah et al., 2013) and from 20.81 to 25.99\% (Simsek and Kizmaz, 2017). In the present study, the crude protein (Cp) contents agreed mostly well with earlier reports (Barbera et al., 1984; Soler et al., 1989; Mbah et al., 2013; Simsek and Kizmaz, 2017). Because the crude protein (Cp) content is high, the almond genotypes and cultivars may serve as dietary supplements for unhealthy people who require crude protein and suffer from hypertension. Sugar is found in both almond kernels and other plant tissues, and can be digested, absorbed and metabolised by humans to provide energy. In this study, because the genotypes SAHI232, SAHI250, SAHI278, SAHI301 and SAHI324, and the variety FERRAGNES have a sugar content greater than $4 \%$, they are rich of sugar. In previous works, the total sugar (Ts) content ranged from 2.56 to $4.17 \%$ (Aslantas et al., 2001), from 3.10 to 5.30\% (Romojaro et al., 1988), from 2.60 to $4.00 \%$ (Kazantzis et al., 2003), from 2.10 to $7.40 \%$ (Ahrens et al., 2005) from 2.10 to $5.50 \%$ (Amrein et al., 2005) and from 2.91 to $4.06 \%$ (Simsek and Kizmaz, 2017). In the present study, total sugar (Ts) content in harmony with earlier studies (Aslantas et al., 2001; Romojaro et al., 1988; Kazantzis et al., 2003; Ahrens et al., 2005; Amrein et al., 2005; Simsek and Kizmaz, 2017).

The importance of the moisture content of the kernels is great. Enzymatic activities in fruit with high moisture are higher than those in dry fruits. In general, the availability of moisture (Mo) encourages the growth of microorganisms and hence microbial spoilage of food, so it is not advisable to store almond kernels fresh. It has been determined that genotypes and varieties in this study do not have high moisture. In various studies, the moisture (Mo) contents changed from 3.08 to $4.43 \%$ (Simsek and Demirkiran, 2010), from 3.49 to $4.96 \%$ (Oliveira Sousa et al., 2011) and from 2.28 to $3.70 \%$ (Simsek and Kizmaz, 2017). In the present study, the moisture (Mo) content agreed with earlier data (Simsek and Demirkiran, 2010; Oliveira Sousa et al., 2011). The moisture (Mo) content should be reduced by drying to increase the safe storage time. The total ash ( $\mathrm{Ta}$ ) content was reported from 2.54 to $4.42 \%$ (Simsek and Demirkiran, 2010), from 2.74 to 3.05\% (Ozcan et al., 2011), from 3.50 to $4.10 \%$ (Mbah et al., 2013), from 2.60 to $4.60 \%$ (Ahrens et al., 2005), from 2.30 to $3.70 \%$ (Ruggeri et al., 1998) and from 3.12 to $4.69 \%$ (Simsek and Kizmaz, 2017). Ash contents are in harmony with earlier reports (Simsek and Demirkiran, 2010; Ozcan et al., 2011; Mbah et al., 2013; Ahrens et al., 2005; Ruggeri et al., 1998; Simsek and Kizmaz, 20017). All genotypes and varieties except for SAHI250 and SAHI301 genotypes with respect to crude oil, all genotypes with respect to crude protein values and the genotypes SAHI232, SAHI250, SAHI278, SAHI301 and SAHI324, and the variety FERRAGNES with respect to sugar contents in this study are very important. Proximate acid compositions of almond genotypes and cultivars can change according to the genetic differences, maintenance and ecological conditions. 


\section{Mineral composition of sweet almond genotypes and cultivars}

In this study carried out on the almond genotypes and commercial varieties named as Ferragnes and Ferraduel grown in the same location known as the Firat riverside region during two consecutive years, the mineral composition of the genotypes and varieties were compared at the same location. According to the results from the one-way ANOVA analysis, the differences between the mineral contents of the genotypes and/or the varieties were shown in different letters statistically and were presented in Table 3. In this context, the most abundant minerals are potassium $(\mathrm{K})$ and phosphorus $(\mathrm{P})$, followed by magnesium $(\mathrm{Mg})$ and calcium $(\mathrm{Ca})$, while sodium, $(\mathrm{Na})$ iron $(\mathrm{Fe})$, zinc $(\mathrm{Zn})$, manganese $(\mathrm{Mg})$ and copper $(\mathrm{Cu})$ are scarce. Among the minerals studied, potassium $(\mathrm{K})$, the phosphorus $(\mathrm{P})$, magnesium $(\mathrm{Mg})$, and calcium $(\mathrm{Ca})$ contents were the highest compared to the other minerals. However, all of the sodium $(\mathrm{Na})$, iron $(\mathrm{Fe})$, zinc $(\mathrm{Zn})$, manganese $(\mathrm{Mg})$ and copper $(\mathrm{Cu})$ were only present at trace amounts. Our results are in agreement with the mineral contents for kernels of several almond genotypes and cultivars described in previous studies. In this context, Aslantas et al. (2001) found that mineral contents of selected almond genotypes naturally grown in

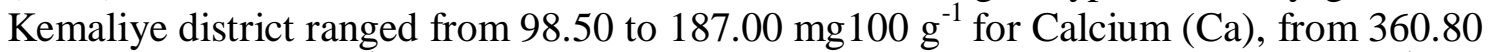
to $513.40 \mathrm{mg} 100 \mathrm{~g}^{-1}$ for Magnesium $(\mathrm{Mg})$, from 403.90 to $800.00 \mathrm{mg} 100 \mathrm{~g}^{-1}$ for phosphorous (P), from 1677.30 to $2051.10 \mathrm{mg} 100 \mathrm{~g}^{-1}$ for potassium (K). Ozcan et al. (2011) determined that mineral contents of five almond cultivars collected in Antalya and Mugla provinces ranged from 1315.00 to $1510.00 \mathrm{mg} 100 \mathrm{~g}^{-1}$ potassium $(\mathrm{K})$, from 793.00 to $938.00 \mathrm{mg} 100 \mathrm{~g}^{-1}$ phosphorous (P), from 298.00 to $404.00 \mathrm{mg} 100 \mathrm{~g} \mathrm{~g}^{-1}$

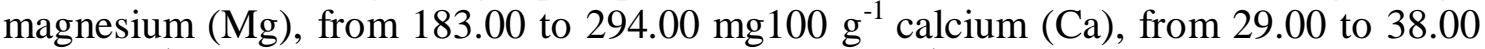
$\mathrm{mg} 100 \mathrm{~g}^{-1}$ sodium (Na), from 20.00 to $27.00 \mathrm{mg} 100 \mathrm{~g}^{-1}$ iron $(\mathrm{Fe})$ and from 4.00 to 6.00 mg100 $\mathrm{g}^{-1}$ zinc (Zn), respectively. Simsek and Kizmaz (2017) determined that mineral contents of almond genotypes grown in Beyazsu district ranged from 646.27 to 925.13 $\mathrm{mg} 100 \mathrm{~g}^{-1}$ potassium (K), from 562.53 to $701.93 \mathrm{mg} 100 \mathrm{~g}^{-1}$ phosphorous (P), from

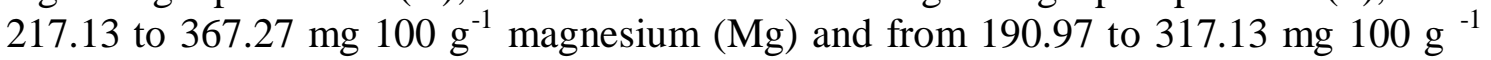
calcium (Ca), respectively. Saura Calixto and Canellās (1982) observed that mineral composition of seven sweet almond varieties ranged from 649.00 to $824.00 \mathrm{mg} 100 \mathrm{~g}^{-1}$ potassium (K), from 462.00 to $595.00 \mathrm{mg} 100 \mathrm{~g}^{-1}$ phosphorous (P), from 239.00 to

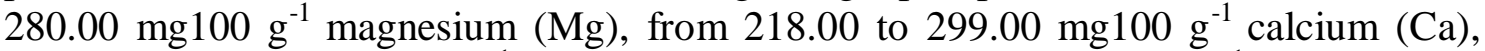
from 4.80 to $12.50 \mathrm{mg} 100 \mathrm{~g}^{-1}$ sodium $(\mathrm{Na})$, from 3.10 to $4.40 \mathrm{mg} 100 \mathrm{~g}^{-1}$ iron (Fe) and from 0.90 to $1.30 \mathrm{mg} 100 \mathrm{~g}^{-1}$ copper $(\mathrm{Cu})$. Barbera et al. (1984) reported that mineral composition of two almond varieties changed from 1546.00 to $1685.00 \mathrm{mg}^{-100 \mathrm{~g}^{-1}}$ potassium $(\mathrm{K})$, from 253.00 to $259.00 \mathrm{mg} 100 \mathrm{~g}^{-1}$ phosphorous (P), from 640.00 to $678.00 \mathrm{mg} 100 \mathrm{~g}^{-1}$ calcium (Ca), from 447.00 to $494.00 \mathrm{mg} 100 \mathrm{~g}^{-1}$ magnesium $(\mathrm{Mg})$,

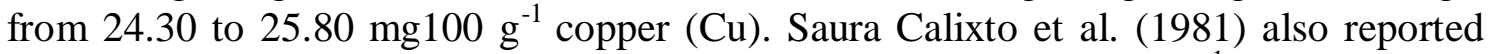
that mineral contents of almond cultivars consisted of $766.00 \mathrm{mg} 100 \mathrm{~g}^{-1}$ potassium $(\mathrm{K})$, $364.00 \mathrm{mg} 100 \mathrm{~g}^{-1}$ phosphorous $(\mathrm{P}), 227.00 \mathrm{mg} 100 \mathrm{~g}^{-1}$ magnesium $(\mathrm{Mg})$ and 185.00 mg100 $\mathrm{g}^{-1}$ calcium $(\mathrm{Ca})$. In general, the mineral contents in this study agreed with earlier reports (Barbera et al., 1984; Saura Calixto et al., 1981; Saura Calixto and Canellās, 1982; García-López et al., 1996; Aslantas et al., 2001; Ozcan et al., 2011; Simsek and Kizmaz, 2017). Considering macro and micronutrient values in this study, $\mathrm{K}, \mathrm{P}, \mathrm{Ca}$ and $\mathrm{Mg}$ (macro nutrients) and $\mathrm{Na}, \mathrm{Mn}, \mathrm{Fe}, \mathrm{Cu}$ and $\mathrm{Zn}$ (micro nutrients) in all genotypes and varieties are important and statistically significant.

The minerals of almonds and other nuts are obtained from the soil and water applied during production. Thus, the mineral contents of almond kernels are affected by many 
ecological factors and agronomic practices including geographic location, soil composition, water source, irrigation regime, fertiliser components, and other aids to agronomic production. The mineral content can be influenced by plant genotypes, cultivars, maintenance and ecological conditions.

\section{Fatty acid composition of sweet almond genotypes and cultivars}

Fatty acid content is the most common feature for fat and oil characterization. It is related to oxidative stability as well as to some nutritional characteristics. In this study carried out on the almond genotypes and commercial varieties named as Ferragnes and Ferraduel grown in the same location known as the Firat riverside region during two consecutive years, the fatty acid compositions of the genotypes and varieties were compared at the same location. According to the results from the one-way ANOVA analysis, the differences between the proximate composition of the genotypes and/or the varieties were shown in different letters statistically and were presented in Table 4. Fatty acid composition of sweet almond genotypes and cultivars were presented in Table 4. Oleic (Oa) and linoleic acid (La) contents of sweet almond genotypes and cultivars were established as major fatty acids. The samples are rich in both oleic (Oa) and linoleic acids (La). However, they may be used as edible cooking and salad oils.

In previous works, Kiani et al. (2015) reported that some fatty acid contents of 40 wild-growing almond accessions ranged from 0.40 to $0.80 \%$ palmitoleic acid (Paa), from 1.00 to $3.40 \%$ stearic acid (Sa), from 4.60 to $9.50 \%$ palmitic acid (Pa), from 11.30 to $33.20 \%$ linoleic acid (La) and from 48.80 to $88.40 \%$ oleic acid (Oa). Askin et al. (2007) reported that some fatty acid contents in several almond genotypes ranged from 5.46 to $15.78 \%$ palmitic acid ( $\mathrm{Pa}$ ), from 0.36 to $2.52 \%$ palmitoleic acid (Paa), from 0.80 to $3.83 \%$ stearic acid (Sa), from 50.41 to $81.20 \%$ oleic acid $(\mathrm{Oa})$ and from 6.21 to $37.13 \%$ linoleic acid (La). Celik and Balta (2011) determined that fatty acid contents of some almond genotypes ranged from 6.48 to $6.29 \%$ palmitic acid (Pa), from 0.41 to $0.64 \%$ palmitoleic acid (Paa), from 1.76 to $1.60 \%$ stearic acid (Sa), from 72.02 to $76.41 \%$ oleic acid (Oa) and from 18.92 to $14.71 \%$ linoleic acid (La). Balta (2013) reported that the fatty acid contents of seven almond genotypes ranged from 5.26 to $6.69 \%$ palmitic acid ( $\mathrm{Pa}$ ), from 0.33 to $0.45 .00 \%$ palmitoleic acid (Paa), from 1.61 to $2.40 \%$ stearic acid (Sa), from 65.33 to $74.73 \%$ oleic acid (Oa) and from 17.36 to $25.17 \%$ linoleic acid (La). Martins et al. (2000) determied that fatty acid contents for twelve almond varieties ranged from 2.15 to $3.13 \%$ stearic acid (Sa), from 5.94 to $7.31 \%$ palmitic acid ( $\mathrm{Pa}$ ), from 17.52 to $29.89 \%$ linoleic acid (La) and from 58.96 to $69.68 \%$ oleic acid (Oa). Kodad and Socias I Company (2008) found that fatty acid contents of eight varieties and forty seven almond genotypes ranged from 63.00 to $78.00 \%$ oleic acid (Oa), from 12.00 to $27.00 \%$ linoleic acid (La), from 5.00 to $7.00 \%$ palmitic acid (Pa), from 1.20 to $2.50 \%$ stearic acid (Sa) and from 0.30 to $0.80 \%$ palmitoleic acid (Paa). Sathe et al. (2008) reported that fatty acid contents of eight almond cultivars ranged from 5.07 to $6.78 \%$ palmitic acid (Pa), from 57.54 to $73.94 \%$ oleic acid (Oa), from 19.32 to $35.18 \%$ linoleic acid (La) and from 0.04 to $0.10 \%$ linolenic acid (Lia). The results in this study are consistent with previous works (Kiani et al., 2015; Askin et al., 2007; Celik and Balta, 2011; Balta, 2013; Martins et al., 2000; Kodad and Socias I Company, 2008; Sathe et al., 2008).

Saturated fatty acid (SFA), unsaturated fatty acid contents (UFA) and UFA/SFA ratios in this study were presented in Figures 2, 3 and 4, respectively. Increased uptake of unsaturated fatty acids reduces risk of coronary artery disease. From this point of 
view, it is very important to prevent and treat chronic diseases such as cancer, because it is rich in unsaturated fatty acids, contain significant amounts of antioxidants and phytochemicals. In previous studies, Celik and Balta (2011) reported that fatty acid contents of twenty five almond genotypes ranged from 90.99 to $91.17 \%$ UFA, from 8.82 to $9.00 \%$ SFA and from 10.10 to 10.40 UFA/SFA, respectively. Balta (2013) found that fatty acid contents of almond genotypes ranged from 87.85 to $91.97 \%$ UFA, from 7.99 to $11.59 \%$ SFA and from 7.60 to 11.50 UFA/SFA. SFA and UFA compositions and UFA/SFA in the present study agreed with earlier studies (Celik and Balta, 2011; Balta, 2013). The use of samples with higher fatty acid levels might contribute to almond improvements directed at increasing nutritional value. In addition, fatty acid composition of kernel crude oils (Co) can vary widely among different plant genotypes and cultivars (Ozcan et al., 2011; Aitzetmüller, 1993), county (Sathe et al., 2008), irrigation status (Nanos et al., 2002), climatic conditions, maturity level and soil composition (Kodad and Socias I Company, 2008; Kornsteiner et al., 2006; Moayedi et al., 2011).

\section{Conclusion}

When evaluated statistically, the results in this study show that the sweet almond genotypes and cultivars have high levels of very valuable components. Fatty acids, proximate and mineral contents in particular almond kernel have a very important effect on health and can be included in the diet to improve human health. In this context, All genotypes and varieties except for SAHI250 and SAHI301 genotypes are rich in crude oil because their crude oil content is greater than 50\%. Since all genotypes and varieties have crude protein values greater than $20 \%$, they are protein rich. Because the genotypes SAHI232, SAHI250, SAHI278, SAHI301 and SAHI324, and the variety FERRAGNES have a sugar content greater than $4 \%$, they are rich of sugar. It has been determined that genotypes and varieties in this study do not have high moisture. However, very few studies on minerals have thoroughly assessed different almond genotypes and cultivars in Turkey up to now. Considering macro and micro nutrient values, all genotypes and varieties are important and statistically significant. Almond has beneficial effects on human health since it contains a high level of unsaturated fatty acids / saturated fatty acids (UFA/SFA). UFA/SFA ratios of the genotypes SAHI132, SAHI198, SAHI250, SAHI278, and SAHI302 are greater than 11. Therefore, Adaptation studies should be performed in different ecological conditions with the genotypes SAHI132, SAHI198, SAHI232, SAHI250, SAHI278, SAHI301, SAHI302 and SAHI324, and variety FERRAGNES with other standard almond varieties for determination of commercial purposes and the food industrial applications. As a result, we believe that this study will be of considerable value in light of more detailed work.

\section{REFERENCES}

[1] Agar, I. T., Kafkas, S., Kaska, N. (1998): Effect of cold storage on the kernel fatty acid composition of almonds. - Acta Horticulturae 470(48): 349-356.

[2] Ahrens, S., Venkatachalam, M., Mistry, A. M., Lapsley, K., Sahte, S. K. (2005): Almond (Prunus dulcis L.) protein quality. - Plant Foods for Human Nutrition 60(3): 123-128.

[3] Aitzetmüller, K. (1993): Capillary GLC fatty acid fingerprints of seed lipids-a tool in plant chemotaxonomy? - Journal of High Resolution Chromatography 16(8): 488-490. 
[4] Amrein, T. M., Lukac, H., Andres, L., Perren, R., Escher, F., Amado, R. (2005): Acrylamide in roasted almonds and hazelnuts. - Journal of Agricultural and Food Chemistry 53(20): 7819-7825.

[5] AOAC (1990): Official Methods of Analysis of the Association of Official Analytical Chemists. 15th edition. - Association of Official Analytical Chemists, Washington, DC.

[6] Askin, M. A., Balta, M. F., Tekintas, F. E., Kazankaya, A., Balta, F. (2007): Fatty acid composition affected by kernel weight in almond [Prunus dulcis (Mill.) D. A. Webb.] genetic resources. - Journal of Food Composition and Analysis 20(1): 7-12.

[7] Aslantas, R., Guleryuz, M., Turan, M. (2001): Some chemical contents of selected almond (Prunus amygdalus Batsch) types. - XI GREMPA Seminar on Pistachios and Almonds, Zaragoza CIHEAM, pp. 347-350.

[8] Balta, M. F. (2013): Fatty acid profiles for almond (Prunus amygdalus Batsch) genotypes with different kernel taste and formation. - Iğdır Univ. J. Inst. Sci. \& Tech. 3(1): 17-24.

[9] Barbera, G., DiMarco, L., Schirra, M. (1984): Effect of rootstock on productive andqualitative response of two almond varieties - Acta Horticulturae 373: 129-134.

[10] Basturk, A., Cavidipour, I., Boyaci, J. H. (2007): Oxidative stability of natural and chemically interesterified cottonseed, palm and soybean oils. - Journal of Food Lipids 14(2): 170-188.

[11] Beyhan, O., Aktas, M., Yilmaz, N., Simsek, N., Gercekcioglu, R. (2011): Determination of fatty acid compositions of some important almond (Prunus amygdalus L.) varieties selected from Tokat province and Eagean region of Turkey. - Journal of Medicinal Plants Research 5(19): 4907-4911.

[12] Bliss, F. A. (1999): Nutritional improvement of horticultural crops through plant breeding. - Hort Science 34(7): 1163-1167.

[13] CDO (2018): CLIMATE.DATE.ORG (CDO). - $\quad$ https://tr.climatedata.org/location/15576/ (accessed: 15.04.2018).

[14] Celik, F., Balta, M. F. (2011): Kernel fatty acid composition of Turkish almond (Prunus dulcis L.) genotypes: A regional comparison. - Journal of Food, Agriculture and Environment 9(1): 171-174.

[15] Celik, F., Balta, M. F., Javidipour, L., Dogan, A. (2010): Analysis of oil composition of native almonds from Turkey. - Asian Journal of Chemistry 22(1): 818-820.

[16] FAO (2016): Food and Agriculture (FAO). - http://faostat3.fao.org/download/Q/QC/E.

[17] FRH (2018): Firat River Hilvan (FRH). https://www.google.com.tr/search?q=Firat+Nehri+Hilvan\&safe=active\&source=lnms\&tb $\mathrm{m}=$ isch\&sa=X\&ved=0ahUKEwi5sdfun73aAhXkApoKHZd5AEwQ_AUICigB\&biw=109 3\&bih=510\#imgrc=txKQF4boDYmtZM (accessed: 13.04.2018).

[18] García-López, C., Grané-Teruel, N., Berenguer-Navarro, V., García-García, J. E., MartínCarratalá, M. L. (1996): Major fatty acid composition of 19 almond cultivars of different origins. A Chemometric Approach. - J. Agric. Food Chem. 44(7): 1751-1755.

[19] Jenkins, D. J. A., Kendill, C. W. C., Marchie, A., Parker, T. L., Connelly, P. W., QIan, W., HaIght, J. S., Faulkner, D., Vidgen, E., Lapsley, K. G., Spiller, G. A. (2002): Dose response of almonds on coronary heart disease risk factors-blood lipids, oxidized LDL, Lp (a), homocysteine and pulmonary nitric oxide: a randomized controlled crossover trial. - Circulation 106(11): 1327-1332.

[20] Kaplankiran, M. (1984): Research on the relationship between natural hormone, carbohydrate and plant nutrient levels and growth of some citrus rootstocks. - PhD Thesis, C. U. Science Institute, Adana,Turkey.

[21] Kazantzis, I., Nanos, G. D., Stavroulakis, G. G. (2003): Effect of harvest time and storage conditions on almond kernel oil and sugar composition. - Journal of the Science of Food and Agriculture 83: 354-358.

[22] Kester, D. E., Gradziel, T. M., Grasselly, C. (1991): Almonds (Prunus). - Moore, J. N., Ballington, J. R. (eds.) Genetic Resources of Temperate Fruit and Nut Crops. The International Society for Horticultural Science, Wageningen. 
[23] Kiani, S., Rajabpoor, S., Sorkheh, K., Ercisli, S. (2015): Evaluation of seed quality and oil parameters in native Iranian almond (Prunus amygdalus L.) species. - Journal of Forestry Research 26(1): 115-122.

[24] Kodad, O., Socias I Company, R. (2008): Variability of oil content and of major fatty acid composition in almond (Prunus amygdalus Batsch) and its relationship with kernel quality. - Journal of Agricultural Food Chemistry 56(11): 4096-4101.

[25] Kornsteiner, M., Wagner, K. H., Elmadfa, J. (2006): Tocopherols and total phenolics in 10 different nut types. - Food Chemistry 98(2): 381-387.

[26] Lei, G., Wang, L., Liu, X., Zhang, A. (2014): Chemical composition of essential oils and hydrosols from fresh flowers of Cerasus subhirtella and Cerasus serrulata from East China. - Nat Prod Res 28(21): 1923-1925.

[27] Martins, A. N., Gomes, C., Ferreira, L. (2000): Almond production and characteristics in Algarve, Portugal. - Nucis 2000(9): 6-9.

[28] Mbah, B. O., Eme, P. E., Eze, C. N. (2013): Nutrient potential of almond seed (Terminalia catappa) sourced from three states of Eastern Nigeria. - African Journal of Agricultural Research 8 (7): 629-633.

[29] Moayedi, A., Rezaei, K., Moini, S., Keshavarz, B. (2011): Chemical compositions of oils from several wild almond species. - Journal of the American Oil Chemists' Society 88(4): 503-508.

[30] Nanos, G. D., Kazantzis, L., Kefalas, P., Petrakis, C., Stavroulakis, G. G. (2002): Irrigation and harvest time affect almond kernel quality and composition. - Scientia Horticulturae 96(1-4): 249-256.

[31] Oliveira Sousa, A. G., Fernandes, D. C., Alves, A. M., Freitas, J. B., Naves, B. M. V. (2011): Nutritional quality and protein value of exotic almonds and nut from the Brazilian Savanna compared to peanut. - Food Research International 44(5): 2319-2325.

[32] Ozcan, M. M., Unver, A., Erkan, E., Arslan, D. (2011): Characteristics of some almond kernel and oils. - Scientia Horticulturae 127(3): 330-333.

[33] Piscopo, A., Romeo, F. V., Petrovicova, B., Poiana, M. (2010): Effect of the harvest time on kernel quality of several almond varieties (Prunus dulcis Mill). - Scientia Horticulturae 125(1): 41-46.

[34] Romojaro, F., Riquelme, F., Giménez, J. L., Llorente, S. (1988): Study on carbohydrate fractions in some almonds cultivars of the Spanish southeast. - Fruit Science Reports 15: $1-6$.

[35] Ruggeri, S., Cappelloni, M., Gambelli, L., Nicoli, S., Carnovale, E. (1998): Chemical composition and nutritive value of nuts grown in Italy. - Italian Journal of Food Science 10(3): 243-251.

[36] Sanliurfa (2018): http://sanliurfaprovice.blogspot.com.tr/p/hilvan.html. - Accessed: 12.03.2018.

[37] Sathe, S. K., Seram, N. P., Kshirsaga, H. H., Heber, D., Lapsley, K. A. (2008): Fatty acid composition of california grown almonds. - Journal of Food Science 73(9): C603-C614.

[38] Saura Calixto, F., Canellās, J. (1982): Mineral composition of almond varieties (Prunus amygdalus L.). - Zeitschrift für Lebensmitteluntersuchung und -forschung 174(2): 129131.

[39] Saura Calixto, F., Bauza, M., Martinez de Toda, F., Argamenteria, A. (1981): Amino acids, sugars, and inorganic elements in the sweet almond (Prunus amygdalus L.). - J. Agr. Food Chem. 29(3): 509-511.

[40] Simsek, M. (2016): Chemical, mineral, and fatty acid compositions of various types of walnut (Juglans regia L.) in Turkey. - Bulgarian Chemical Communications 48(1): 6670.

[41] Simsek, M., Demirkiran, A. R. (2010): Determination of superior almond genotypes in Diyarbakir central districts. - Agricultural Journals 5(3): 173-180.

[42] Simsek, M., Kizmaz, V. (2017): Determination of chemical and mineral compositions of promising almond (Prunus amygdalus L.) genotypes from Beyazsu (Mardin) region. International Journal of Agriculture and Wildlife Science 3(1): 6-11. 
[43] Simsek, M., Gulsoy, E., Beyhan, O., Osmanoglu, A., Turgut, Y. (2017): Determination of some botanical, phenological, physical and chemical characteristics of walnut (Juglans regia L.) genotypes grown in Turkey. - Applied Ecology and Environmental Research 15(3): 1279-1291.

[44] Soler, L., Canellas, J., Saura-Calixto, F. (1989): Changes in carbohydrate and protein content and composition of developing almond seeds. - Journal of Agricultural Food Chemistry 37(5): 1400-1404.

[45] TSI (2017): Turkish Standardization Institute (TSI). https://biruni.tuik.gov.tr/medas/?kn=92\&locale=tr (accessed: 15.04.2018). 